\title{
“PERSONALITY OF THE FRONTAL LOBE" IN PATIENTS WITH COMORBIDITY OF BIPOLAR AFFECTIVE DISORDER AND ANTISOCIAL PERSONALITY DISORDER
} "LIČNOST FRONTALNOG REŽNJA“ KOD PACIJENATA
SA KOMORBIDITETOM BIPOLARNOG AFEKTIVNOG
POREMEĆAJA I ANTISOCIJALNOG POREMEĆAJA LIČNOSTI

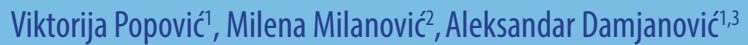

\section{Summary}

Patients with comorbidity of antisocial personality disorder and bipolar affective disorder represent a specific category due to permeation of clinically frequent and most serious mood disorder and a personality disorder of a particularly destructive type such as antisocial personality disorder.

Previous studies of comorbidity of bipolar affective disorder and antisocial personality disorder showed relatively high prevalence rates of bipolar affective disorder in patients with antisocial personality disorder.

In patients with bipolar affective disorder with the presence of antisocial personality disorder it is expected that there is a deterioration of the primary symptoms of the disease, particulary in manic phases, which is the reason of investigation of these phenomena, and why it is essential.

Professional community has been familiar with the impact of neuroanatomic and neurophysiological factors on bipolar affective disorder as well as with antisocial personality disorder for more than two centuries. The most common neuroanatomic studies of patients with bipolar affective disorder and antisocial personality disorder are related to injuries and defects of the frontal cortex in general, whereas neurophysiological tests indicate deficits in brain hemispheres, a low level of excitation of the central and peripheral nervous system, abnormal EEG findings and reduced skin conductivity. Experts have paid special attention to similarities between the so-called "frontal lobe personality" and patients with comorbidity of these disorders.

Analysing some of the basic characteristics of patients with "frontal lobishness" and comparing some research results of neuroanatomic and neurophysiological characteristics of patients with comorbid bipolar disorder and antisocial personality disorder, we try to distance ourselves from the trend that the etiological basis of these disorders is far away from the neurophysiological basis.

Keywords: antisocial personality disorder, bipolar affective disorder, comorbidity, ", frontal lobishness"

\section{Sažetak}

Pacijenti sa komorbiditetom antisocijalnog poremećaja ličnosti i bipolarnog afektivnog poremećaja predstavljaju specifičnu kategoriju usled prožimanja klinički čestog i najozbiljnijeg poremećaja raspoloženja i posebno destruktivnog poremećaja ličnosti kakav je antisocijalni poremećaj ličnosti.

Dosadašnja istraživanja komorbiditeta bipolarnog afektivnog poremećaja i antisocijalnog poremećaja ličnosti ukazuju na relativno visoke stope prevalencije bipolarnog afektivnog poremećaja kod osoba sa antisocijalnim poremećajem ličnosti.

Kod obolelih od bipolarnog afektivnog poremećaja sa prisustvom antisocijalnog poremećaja ličnosti očekivano je da dolazi do pogoršanja simptoma primarnog oboljenja, izuzetno u maničnim fazama, zbog čega je istraživanje ovih fenomena od esencijalne važnosti.

Uticaj neuroanatomskih i neurofizioloških činilaca na bipolarni afektivni poremećaj kao i na antisocijalni poremećaj ličnosti poznat je stručnoj javnosti više od dva veka. Najěešća istraživanja neuroanatomskih karakteristika pacijenata sa bipolarnim afektivnim poremećajem i antisocijalnim poremećajem ličnosti se odnose na povrede i uopšte manjkavosti frontalnog korteksa, dok neurofiziološka ispitivanja ukazuju na deficite moždanih hemisfera, nizak nivo pobuđivanja centralnog i perifernog nervnog sistema, abnormalne nalaze na EEG-u, smanjenu kožnu provodljivost. Posebnu pažnju stručne javnosti pobuđuju sličnosti tzv. „ličnosti frontalnog režnja“ i pacijenata sa komorbiditetom ovih poremećaja.

Analizom osnovnih neuroloških karakteristika pacijenata sa „ličnošću frontalnog režnja“, i poređenjem sa rezultatima istraživanja nekih neuroanatomskih i neurofizioloških karakteristika pacijenata sa komorbiditetom bipolarnog afektivnog poremećaja i antisocijalnog poremećaja ličnosti pokušali smo da se distanciramo od trenda da se etiološka osnova ovih poremećaja udaljava od neurofiziološke baze

Ključne reči: antisocijalni poremećaj ličnosti, bipolarni afektivni poremećaj, komorbiditet, „ličnost frontalnog režnja“

\section{INTRODUCTION}

Antisocial personality disorder is a renamed and more expanded diagnostic concept of the former concept of psychopathy, which is the first personality disorder recognized in psychiatry. In 1801, Parisian psychiatrist Pinel first observed a mental disorder characterized by impulsiveness and (self) destructiveness with a clear understanding of reality in a group of their patients. Describing the case as "madness without delirium" ("Manie sans delire") (1), he indicates that "madness" does not always involve a loss of touch with reality and inability of understanding one's actions, in spite of certain brain dysfunctions. 
Looking at the history of different views of antisocial personality disorder, primarily concerning its etiology, it always implied a personality characterized by impulsiveness, aggressiveness, egocentricity, lack of empathy, low tolerance to frustration, lack of emotions, lack of control, manipulative character, irresponsibility, a constant need of stimulation, early developmental problems, antisocial behavior. On the other hand, it is a person who is aware of their actions, who has preserved the test of reality and has no intelligence deficit. Because of these specific features of patients with antisocial personality disorder (which is rarely the only and exclusive diagnosis), they represent an exceptional phenomenon, a real challenge for studying, particularly their neurophysiological characteristics, and neuroanatomical and neurophysiological basis of the disorder in general, as it can be objectively determined.

Bipolar disorder belongs to the group of mood disorders, characterized by alternating mood swings - states of increased activity and higher energy potential (mania) and phases of grief and decreased activity (depression).

Mood disorders are often simultaneously present with personality disorders. Some studies indicate a relatively high prevalence rate of bipolar affective disorder in people with antisocial personality disorder $(2,3)$. Some of these studies compared characteristics of people with antisocial personality disorder who were also diagnosed with bipolar affective disorder, and among them there were problems in cognitive functioning, as well as the presence of suicidal thoughts compared to the group that was not diagnosed with bipolar affective disorder (4).

It is very important to mention that there were injuries of the prefrontal cortex observed in a significant number of patients together with comorbidity of these disorders (5) and that it is often „personality of frontal lobe“ equivalent to the behavioral and cognitive manifestations of such joint disorders.

\section{THE FRONTAL LOBES}

The frontal lobes cover a large zone of the cerebral cortex, which is approximately or even more than $1 /{ }_{3}$ of the brain surface. This complex anatomical structure is extremely rich and associated with other regions of the brain (brain structures) such as sensory, motor and limbic structures, so in certain situations, frontal pathology can lead to severe behavioral disorders and personality disorders.

The frontal lobe is divided into three surfaces: lateral, medial and inferior. There are four functional regions of the frontal lobes: motor, premotor, prefrontal and limbic. Prefrontal part can be mapped in three regions: dorsolateral, medial and orbitofrontal. Different functional characteristics of these zones are essential for consid- eration of cognitive, behavioral and affective status of patients who have injures of the prefrontal region. It has been discovered that lesions of medial parts cause significant changes in behavior and mood (pseudodepression/ pseudomania) and that the region of orbitofrontal lesions lead to personality disorders and extreme changes at behavioral level (pseudopsichopathy) $(6,7,8,9)$.

\section{INJURES OF THE PREFRONTAL CORTEX}

One of the first scientific descriptions of the consequences that an injury of the prefrontal cortex has on behavior and mood disorder was given by Harlow in 1868 , in the famous case of Phineas Gage (10). The study of this case is known as the "Case of Boston iron bar" or "American crowbar case" and it entered the annals of studying this brain injury region and the changes that occur in personality and behavior following such lesions. Phineas Gage was an American worker who was badly injured by a large iron bar that pierced his skull with an extraordinary strength and was found several tens of meters behind him. The reconstruction determined that, passing through the head, the bar destroyed the left prefrontal cortex and partly the right one. Gage survived this violation and except losing his left eye, he had no other neurological or sensory impairment. Harlow did not notice damage to the patient's intellect either. However Gage's behavior was different - he was irritable, aggressive, rude, and this was followed by lying, mood swings, inability to retain his job, irresponsibility and callousness towards others. Such a behavior disorder fits the guidelines that are now provided for antisocial personality disorder and bipolar affective disorder. This case will be confirmed in numerous studies in future, which will determine the order of behavior disorders and mood swings such as Gage's injuries caused by frontal brain structures.

Recent studies of this phenomenon suggest a strong influence of different neurophysiological processes, pointing at possible interaction of neurophysiological factors and learning. The most common research of neurophysiological factors of bipolar affective disorder and antisocial personality disorder is related to the study using electroencephalography (EEG), galvanic response, any possible deficit in cerebral hemispheres, as well as the level of excitation of the central and peripheral nervous system. Neuroanatomical studies are oriented mainly to attempts to connect the symptomatology of these violations and the general shortcomings of the frontal cortex.

\section{Frontal lobishness - Personality of the FRONTAL LOBE}

The term "frontal lobishness" is hard to translate into Serbian. In the Serbian language it is more frequent to 


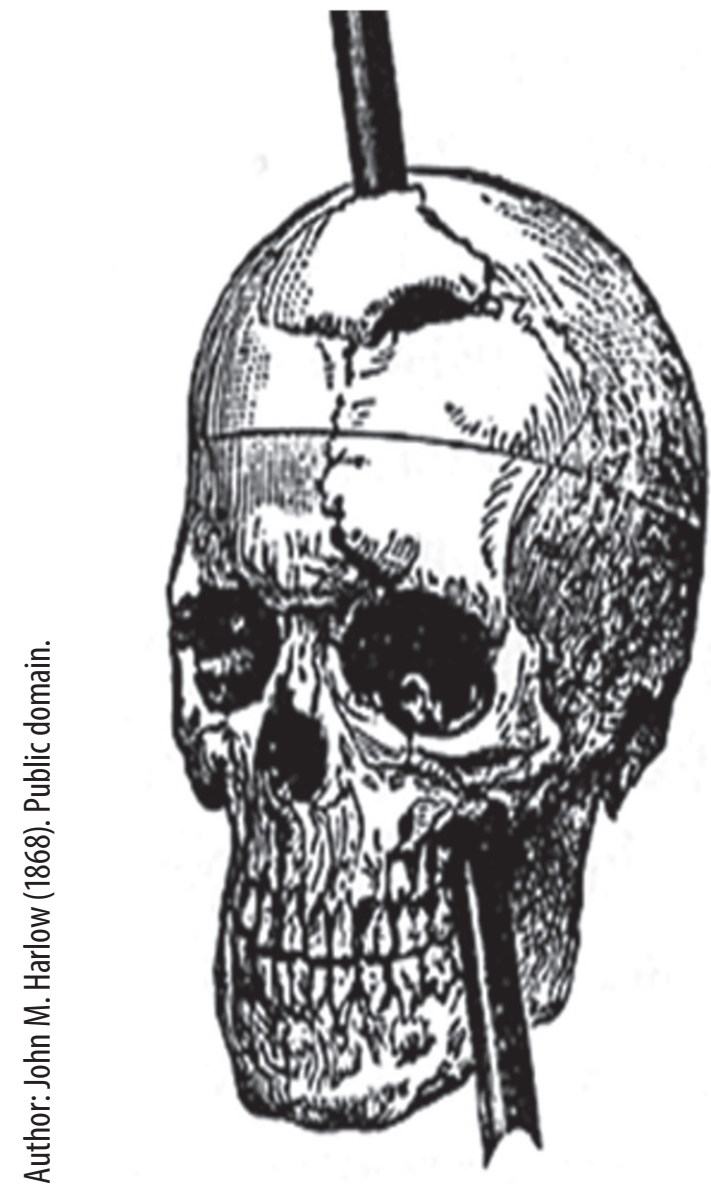

Figure 1. Phineas Gage injury

use the term "personality of the frontal lobe“ (ličnost frontalnog režnja).

The concept of „personality of the frontal lobe“ simultaneously relies on several things - an easy recognition of the phenomenon, problematic prediction of symptom development, numerous similarities with personality disorders (especially antisocial personality disorder) and mood disorders. Radical changes in personality and behavior with generally preserved intellectual and sensory - motor functions are the basic characteristics of the „personality of the frontal lobe“. A set of specific characteristics of patients with frontal damage that define these patients include moria, Witzelsucht, infantilism, indecency, irresponsibility, grandiosity, impetuosity, aggressiveness, affective instability (the whole range from depression to mania), emotional emptiness, stubbornness, self-centeredness (11).

Comorbidity of antisocial personality disorder and bipolar affective disorder often gives the clinical picture, which in most cases coincides with the "personality of the frontal lobe". Numerous studies have confirmed that damage to the frontal lobes leads to the "frontal pathology", which is characterized by extreme changes in personality and behavior $(12,13)$. After orbitofrontal leucotomy some authors describe patients with hyperactivity and extraversion (14).
Behavioral syndrome due to the injury of the frontal lobes is manifested predominantly by changes in the sphere of social functioning (12). Complex aspects of social functioning of patients with lesions of the frontal lobes are manifested by aggressive and impulsive behavior, irritability, disregarding social norms, substance abuse. Total loss of inhibition is accompanied by strong affective changes, such as the state of extreme energy and excitement that alternates with phases of withdrawal and sadness, as well as paradoxical conditions that some authors describe as apathic irritability (15).

Research results including subjects who suffered from various violations of frontal brain regions, as well as persons with confirmed presence of a tumor or its removal, gave an idea to some authors to divide personality changes these patients suffered from in two groups: pseudodepressive syndrome characterized by apathy, slowness in all fields, lowered instincts, low emotionality, and pseudopsychopathy syndrome marked by impulsivity, selfishness, indifference to the needs and the wellbeing of others, elevated mood and irritability (16). The authors make a difference between these syndromes and real disorders such as depression/mania or psychopathy. For us, both are interesting, especially because of compatibility with affective bipolar disorder or antisocial personality disorder. Pseudopsychopathy syndrome corresponds with provisions of antisocial personality disorder, which the abovementioned experts claim to have the same external manifestations as psychopathy (aggressiveness, impulsiveness, irritability, hedonism, Machiavellism, lack of empathy and no concern for others whatsoever), and are quite difficult to distinguish $(16,17)$. But the core of antisocial personality disorder, which is represented by treachery and premeditation, definitely does not exist in pseudopsychopathy, which is one of the few differences between these phenomena. In pseudopsychopathy syndrome it is observed that changes occur due to damage to the orbitofrontal region. Pseudodepressive/ pseudomanic syndrome characterized by apathy, low instincts, loss of initiative, which alternates with euphoria and exhilaration is stated groundless. This syndrome occurs due to damage to the anterior convexity and medial parts of the frontal lobes.

Esslinger and Damasio have similar starting points (18), presenting the case of a patient called EVR, aged thirty-five and operated for brain tumor of the frontal region, who experienced drastic changes in his personality and behavior after the removal of the tumor (including the removal of parts of the frontal lobes). EVR shows inability to learn from experience (from mistakes and penalties), he is incapable of keeping a job, he constantly changes marital and sexual partners, he has unreasonable management of money and property that has lead him to bankruptcy and he manifests the development of a series of socially unacceptable qualities that EVR did not have earlier, before the surgery. 
Based on this behavior the authors recognize the symptoms identical to sociopathic personality disorder (the equivalent of today's anti-social personality disorder) from the then current DSM - III classification (19), and this situation is called "acquired sociopathy" because it is reported in adulthood, following a brain damage. In later works, Damasio (6) highlights the distinction between „acquired“ and „developmental“ sociopathy, considering the former possibility of socially acceptable behavior as the main feature of "acquired sociopathy", which has never existed in "developmental sociopathy“. It also represents the basic difference between these two categories of "sociopaths", as most of the troubles "acquired" sociopaths have are due to damage inflicted to their behavior, unlike "developmental sociopaths" whose troubles are provoked by rules concerning others, but almost never themselves.

\section{NEUROPHYSIOLOGICAL PROCESSES IN PATIENTS WITH COMORBIDITY OF BIPOLAR DISORDER AND ANTISOCIAL PERSONALITY DISORDER}

The most common studies of neurophysiological processes in patients with comorbid bipolar disorder and antisocial personality disorder were conducted with the help of EEG and usually resulted in abnormal findings, noticing the incidents of brain activity or unusually slow brain waves (20). Among the first studies testing the EEG on a person with antisocial personality disorder with a possible presence of mood disorders, there was a research conducted during World War II. Pioneers of these studies, Hill and Watterson, had a sample of 104 patients from a psychiatric institution who they divided into two groups: aggressive psychopaths (impulsive, aggressive, compulsive and antisocial) and inadequate psychopaths (passive, depressed, self-centered and perverse) (21). According to this study, abnormal electroencephalographic findings were found in $60 \%$ of respondents from the group of aggressive psychopaths, and $32 \%$ from the group of inadequate psychopaths. EEG abnormality was mainly manifested in the form of slower brain activity, which has been confirmed by other authors in subsequent studies, such as those conducted by Ehrlich and Keogh, who found even $88 \%$ of abnormal electroencephalogram in the psychopaths they reviewed (22).

The connection between slowed brain activity with delayed cortical maturation in individuals who exhibit psychopathic symptoms associated with striking affective fluctuations, particularly aggressive, impulsive and antisocial behavior, is associated with a tendency towards stagnating antisocial behavior as people get older. This attitude leads to the conclusion that the cortex of these patients is slower, resulting in later maturation of the brain of members of normal adult population. It is interesting to note that abnormal EEG findings (usually different oscillation) in normal population are found in $15 \%$ of cases (23) or in $5-20 \%$ of cases (24), depending on the author.

Many facts about the neurophysiological bases of bipolar affective disorder and antisocial personality disorder were found in studies of the problems concerning functioning of these patients' brain hemispheres (25). These studies were mainly directed towards determining certain abnormalities in the left hemisphere, in the majority of cases. Simply put, the left hemisphere is responsible for verbal communication and language, as well as for analyzing the received information, while the right hemisphere covers non - verbal functions and is particularly important for understanding, complex understanding and processing of the information which is received. These studies have attempted to link verbal communication of people who suffer from antisocial personality disorder with the environment and the inconsistency of what they say and what they do. This incompatibility of speech and things they do and their failure to recognize the meaning of spoken words are probably best described in Cleckey's work and is known as „semantic dementia“ (26).

The presence of left - handedness in patients with comorbidity of bipolar disorder and antisocial personality disorder and attempts to make a connection between this population and more frequent use of their left arm, has been confirmed by the fact that a number of people with antisocial disorder is left-handed (which is proved to be more common than left - handedness presence in mass population) (27). However, there are proofs for the opposite as well; for example, right - handed people with antisocial personality disorder are far more aggressive than left - handed people from the same category, especially when it comes to offenses (28). Interestingly, the data from some studies show that left-handedness is almost non-existent in patients with bipolar affective disorder and that the comorbidity of these disorders and left-handedness is minimal (29). Scientists have attempted to identify neurological abnormalities in these patients in research of defective reflexes and generally unwanted movements, such as tics and tremors. Sessions-Hodge in his research notes that $78 \%$ of offenders who were diagnosed with antisocial personality disorder with the presence of affective disorder have a tremor of fingers and abnormal reflexes, as opposed to only $8 \%$ of cases in the control group (30).

Probably the most common test of neurophysiological characteristics of patients with comorbidity of these disorders is related to the connection of vigilance with the level of stimulation that the brain will receive from the environment. The need for stimulation is individual, but this category is attributed to hypo autonomic nervous system, which is directly linked with poorer learning from experience, the inability to predict consequences 
that will often produce aggressive behavior, as well as the continuous search for stimulation. Because of these symptoms, it is certain that this is a population with a strong need for stimulation, at all costs, which disrupts all other functions, putting them in a situation to cause stimulation and exercise risky or prohibited acts. Neurophysiological aspects have often been studied by establishing the absence of anxiety in these people in shocking and stressful situations. The results show that people with antisocial personality disorder feel less tension before a stressful situation, whereas during stress and shortly after stress they feel greater anxiety, but they far more quickly return to their normal physiological functioning, compared to the mass population. Lindner is one of the pioneers of these studies in patients with bipolar affective disorder and psychopathic offenders (31). Experiments of this type are usually carried out by giving electric shocks to respondents in both groups. Recent studies of this type have supported these pioneers' findings (32).

In the domain of psychophysiology there were conducted numerous studies that were routed in the study of links between anxiety and physiological deficiencies in persons with antisocial personality disorder associated with bipolar disorder. In order to study galvanic reactions (skin conductance) with emotional excitation of psychopaths with skin irritation, Hare and Quinn (33) concluded that skin conductivity is much lower in this population compared to normal population. It was confirmed by testing galvanic reactions that psychopaths had a lower level of tension in stressful situations and that owing to this adaptation to stress they tolerated such a situation much better than mass population, as well as that they recovered more quickly and more successfully from stressful situations, which lead to the conclusion that psychopaths in the learning process are not primarily motivated by tension and fear, and therefore have difficulties to learn from their mistakes and continue to be problematic and antisocial (34).

With a multitude of studies that dealt with nerve structures which may be responsible for aggressive and impulsive behavior in patients with comorbid bipolar disorder and antisocial personality disorder, there are also studies that consider changes in the level of the hormone testosterone in men or concentration of estrogen and prolactin growth in women $(35,36)$ as well as other chemical substances in blood, usually glucose level (37).

\section{Conclusion}

Numerous studies in the field of establishing neurophysiological and neuroanatomical characteristics of persons with comorbidity of bipolar disorder and antisocial personality disorder provide evidence of a strong biological basis for this joint disorder. These findings encourage new tests and suggest further work to identify their origin, not only from the aspect of psychiatric practice, but also as an actual problem today that is increasingly characterized by aggressive and impulsive outbursts of modern man without clearly discernible pathology.

Exceptional similarity between „frontal lobe personality" and the symptoms manifested by patients with comorbid bipolar disorder and antisocial personality disorder points at the unbreakable link between these phenomena, with special emphasis on some common neuroanatomical and neurophysiological bases.

\section{References}

1. Millon T, Simonsen E, Birket-Smith M. Historical Conceptions of Psychopathy in the United States and Europe. In: Millon T., Simonsen E., Birket-Smith M., Davis RD.(Eds.) Psychopathy - Antisocial, Criminal and Violent Behavior. New York - London:The Guilford Press. 2003; 3-32.

2. Latalova K, Prasko J, Kamaradova D. et al. Comorbidity bipolar disorder and personality disorders, Neuroendrocinology Letters, 2013; 34: 1-8.

3. Swann AC, Lijffijt M, Lane SD, Kjome KL, Steinberg JL, Moeller FG. Criminal conviction,impulsivity, and course of illness in bipolar disorder. Bipolar Disorders. 2011; 13:173-181.

4. Swann AC, Lijffijt SD, Lane SD, Steinberg JL, Moeller FG. Interactions between bipolar disorder and antisocial personality disorder in trait impulsivity and severity of illness. Acta Psychiat Scand. 2010; 121(6): 453-461.

5. Brower MC, Price BH. Neuropsychiatry of frontal lobe dysfunction in violent and criminal behaviour: A critical review. Journal of Neurology, Neurosurgery and Psychiatry. 2001; 71(6):720-726.

6. Damasio AR. A neural basis for sociopathy. Archives of General Psychiatry. 2000; 57:128-129.

7. Finger EC, Marsh AA, Mitchell DG. et al. Abnormal ventromedial prefrontal cortex function in children with psychopathic traits during reversal learning. Archives of General Psychiatry. 2008; 65(5):586-594.

8. Sarkar S, Clark BS, Deely Q. Differences between psychopathy and other personality disorders: Evidence from neuroimaging. Advances in Psychiatric Treatment. 2011; 17(3):191-100.

9. Hawkins KA, Trobst KK. Frontal lobe dysfunction and aggression: Conceptual issues and research findings. Aggression and Violent Behavior. 2000; 5(2):147-157.

10. Harlow JM. Recovery from the passage of an iron bar through the head. History of Psychiatry. 1993 (1869); 4(14):274-281.

11. Mesulam MM. Frontal Cortex and Behavior. Annals of Neurology. 2004; 19(4): 320-325.

12. Damasio AR, Tranel D, Damasio HC. Individuals with sociopathic behavior caused by frontal damage fail to respond autonomicalyy to social stimuli. Behavior Brain Research. 1990; 41:81-94.

13. Strezer P, Stadler C, Poustka F, Kleinschmidt A. A structural neural deficit in adolescents with conduct disorder and its association with lack of emapthy. Neuroimage. 2007; 37(1):335-342.

14. Robison AR, Taghva A, Liu CY, Apuzzo LJ. Surgery of the mind, mood and conscious state: An idea in evolution. World Neurosurgery. 2013; 80(3-4):2-26.

15. Aron AR, Robbins TW, Poldrack RA. Inhibition and the right inferior frontal cortex. Trends in Cognitive Science. 2004; 8(4): 170-177.

16. Blumer D, Benson DF. Personality changes with frontal and temporal lobe lesions. In: Benson D. F., Blumer D. (Eds.). Psychiatric aspects of Neurologic Disease. New York: Grune and Stratton. 1975; 151 - 169.

17. Hoffer ZS, Allen SL, Mathews M. Treatment of psychiatric symptoms associated with frontal lobe tumor through surgical resection. The American Journal of Psychiatry. 2007; 164(6): 877-882. 
18. Eslinger PJ, Damasio AR. Severe distrubance of higher cognition after bilateral frontal lobe ablation: Patient EVR. Neurology. 1985; 35: 1731 - 1741 .

19. American Psychiatric Association, Diagnostic and statistical manual of mental disorders (3rd. Ed.). Washington, DC: American Psychiatric Association. 1980.

20. Tiihonen J, Rossi R, Laakso MP et al. Brain anatomy of persistent violent offenders: More rather than less. Psychiatry Research. 2008; 163(3): 201-212

21. Hill D, Watterson D. Electroencephalographic Studies of the Psychopathic Personality. Journal of Neurology and Psychiatry. 1942; 5:47-64.

22. Ehrlich SK, Keogh RP. The Psychopathic in a Mental Institution. Archives of Neurology and Psychiatry. 1956; 76: 286-295.

23. Gibbs EL, Lennox WG. Classification of Epileptic Patients and Control Subjects. Archives of Neurology and Psychiatry. 1963; 50-111.

24. Meloy JR. The psychopathic Mind: Origins, Dynamics and Treatment. Lanham: Rowan \& Littlefield. 2002; 20-38.

25. Hiatt KD, Newman JP. Behavioral evidence of prolonged interhemispheric transfer time among psychopathic offenders. Neuropsychology. 2007; 21(3):313-318.

26. Cleckey H. Mask of Sanity, Fifth edition: private printing for non-profite educational use. 1988. Available at http://www.cassiopaea.org/cass/ sanity1.PdF.

27. Wardell D, Yeudall LT. A multidimensional approach to criminal disorders: The assessment of impulsivity and its relation to crime. Advances in Behaviour Research and Therapy. 1980; 2(4): 159-177.

28. Andrew J. Are left handers less violent? Journal of Youth and Adolescence. 1980; 9:1-9.
29. Oliviera-Souza R, Hare RD, Bramati IE. et al. Psychopathy as a disorder of moral brain: Fronto-temporo-limbic grey matter reductions demonstrated by voxel-based morphometry. NeuroImage. 2008; 40(3):1202-1213.

30. Sessions-Hodge R. The impulsive psychopath: A clinical and electrophysiological study. Journal of Mental Science. 1945; October.

31. Lindner R. Experimental Studies in Constitutional Psychopathic Inferiority. Part II. Journal of Criminal Psychopathology. 1943; 4: 484 -500.

32. Kiehl KA, Smith AM, Hare RD et al. Limbic abnormalities in affective processing by crimnal psychopaths as revealed by functional magnetic resonance imaging. Biological Psychiatry. 2001; 50(9): 677-684.

33. Hare RD, Quinn M. Psychopathy and autonomic conditioning. Journal of Abnormal Psychology. 1971; 77:223-235.

34. Fairchild G, Van Goozen SH, Stollery SJ, Goodyer IM. Fear conditioning and affective modulation of the startle reflex in male adolescents with early-onset or adolescence-onset conduct disorder and healthy control subjects. Biological Psychiatry. 2008; 63(3):279-285.

35. Yildirim BO, Derksen JJL. A review on the relationship between testosterone and life-course persistent antisocial behavior. Psychiatry Research. 2012; 200(2-3): 984-1010.

36. Ramirez JM. Hormones and aggression in childhood and adolescence. Aggression and Violent Behaviour. 2003; 8(6): 621-644

37. Cetin M, Cilden S, Basoglu S et al. Neuroendocrinergic and biochemical inidacators of aggressive behaviour and violence. European Neuropsychopharmacology. 1998; 8(2): 313. 